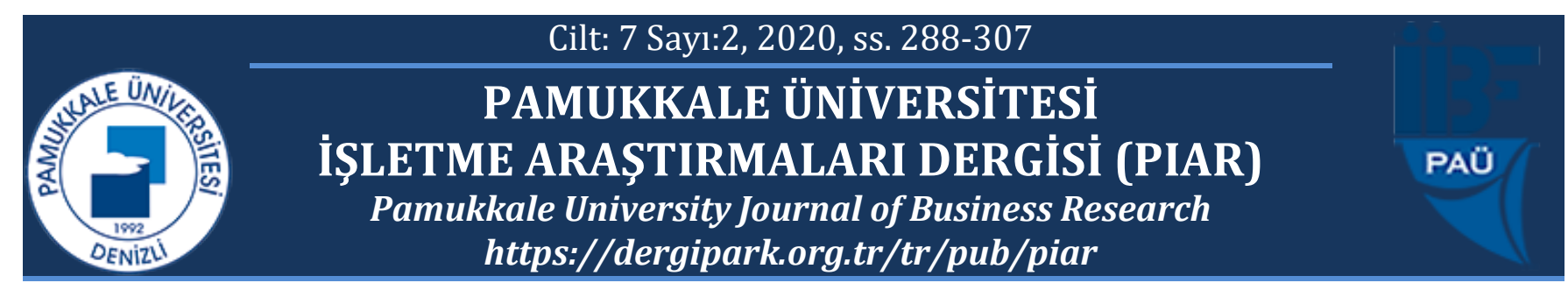

\title{
Crisis Management: A Way Towards Being Human
}

\author{
Avdhesh JHA ${ }^{1 *}$ \\ ${ }^{1}$ Waymade College of Education, CVM University, INDIA, jhaavdhesh@yahoo.co.in, https://orcid.org/0000-0002-8362- \\ $848 \mathrm{X}$ \\ * Yazışılan Yazar/Corresponding author
}

Makale Geliş/Received: 20.11.2020

Makale Kabul/Accepted: 09.12.2020

\begin{abstract}
As an exploratory research, the study was conducted with an objective to create a simple and understandable process of crisis management. Based on the review of literature, it was hypothesized that people preparing for a crisis, face the barrier of helplessness but step ahead to pacify their needs. In order to obtain data, interviews were conducted with the masons, factory workers, house keepers, maids and servants, salaried people and businessmen who responded as the respondents. Content analysis, analysis and synthesis, grouping, mind mapping and thematic analysis was applied to understand the process of crisis management amongst the people. The analysis and synthesis method were used to group the similar responses. Based on this analysis, several reasons were identified and based on synthesis several deductions were made for mind mapping which led to the visual representation of the stages in the process of crisis management. Association analysis was applied to connect and develop the relationship amongst the stages as well study the influence of the actions in each stage. Using a mind map and content analysis, a logical sequence of the characteristics and their relationships within the entire crisis management process was established in five stages and nine sub-stages. Further research needs to be conducted to verify and ascertain the validity of the stages and sub-stages.
\end{abstract}

Keywords: crisis; crisis management; CM; SCM; human; humanity; pandemic; epidemic

JEL codes: M1, M2 


\section{INTRODUCTION}

The world with terror of pandemic having the power and strength to attack the human body, mind and soul is in critical phase. In fact it is a case of crisis which requires crisis management. A crisis is a progressive process that may not be restricted to one area within a common border. It may ensnare rapidly and emerge with other crises, and its consequences are extended (Hart, Heyse \& Boin, 2001). This also means stepping outside of what is comfortable, usual or expected, and it can be a chance for people to shine (Civelek, $C_{3}$ emberci \& Eralp, 2016). Coombs and Hollady (2012) highlight the fact that not every crisis is triggered by a 'problem'. According to Marie \& Petra (2019) a crisis typology is a structured approach to analysing crisis situations and to introduce measures for crisis prevention and containment. Approaches to the crisis management selection strategy consider the internal and external environment (Litovchenko, 2012). These approaches to a crisis are a fundamental aspect of the systematic process of crisis management. In order to answer the deep existential questions that occur during a crisis, these are applied to different defensive strategies ( $\mathrm{T}^{\sim}$ anase, 2012). Coombs and Hollady (2012) present an approach describing crisis management as three processes - the pre-crisis (prevention and preparation), the crisis (response) and the post-crisis (learning and revision). In 21st century, when the human ambition and strife leads the human mind to far of galaxies and planets; directly or indirectly, this micro-organism has affected the whole world in such a way that the world is shocked and shattered with the impact of its terror. The fast spread of this virus has attacked the human existence and its harmony but human is no less to raise itself in any situation. The most terrible impact of COVID 19 and the lockdown was seen on human. With the lockdown was posited several controls which arouse several questions. The curiosity didn't allow the human to keep away from the media and news whereas the livelihood didn't allow him to rest at ease. It was only this situation that forced the human to think of life and livelihood and anyone whether economically sound or unsound initiated with selection of life. Maybe the increased terror of corona, its impact or any similar situation which posits the fear of life and endangers the existence; whenever such a situation arises with the individuals who are the earning member and above the age of 18, they undergo a crisis. Whereas it sounds very simple, this situation, in fact is very crucial. In the present study, with the unwanted and unpredicted happening, mishap, accident or event; with no choice or with conflicting forces as choice for life and/or existence; with a forced acceptance of that situation and that too with lack of readiness for the situation, the crisis is said to occur. The crisis may present the individual with the options comprising of the conflicting forces. The response (as a choice of conflicting forces) of the individual towards the crisis from among the conflicting forces is called Crisis Management. Hereby, the wanted or unwanted, forced or willing choice as a response to such conflicting forces emerged of the crisis is a step towards crisis management. Such a situation posits several questions related to crisis and crisis management which forms the premise for this study.

\section{CRISIS AND HUMAN BEHAVIOUR}

With any crisis occurring to an individual, normally the individual tries not to accept it, strives for alternate ways, opts to avoid it, undergoes conflicts, suffers of anxiety, stress and fatigue leading to depression, in case of forced unwilling choices to opt the individual turns angry, impolite and rude but ultimately with no way out accepts it and starts responding to 
it as per the situation. Throughout life, at times, individuals suffer of the failure in love or relationship, forced quitting of job, work life balance, family problems, extra marital relations, divorce, inability to satisfy the ambitions and aspirations whereby they face this crisis which forces them to go for crisis management as a counterbalance. Thus the unwanted situation with ambiguous choices turns him perplexed and confused and the forced selection of the unwanted choices/options turns him angry because he doesn't want to accept this situation. If he is able to find the solution, its fine but in other case, this situation turns him full of anxiety, fatigue, stress and sometimes even leads to worry which further leads to dissatisfaction, distrust and thus depression. Hereby whereas a little of common sense, care, courage, caution, control, discipline, patience, hope, selfless action and trust leading towards being humane (hereby indicates being good to ourself and others, being at ease and at peace with self, family, community or members of society or all of these) is required, in most cases because of lack of resources it remains restricted to need gratification which leads towards carelessness, restlessness, recklessness, indiscipline, impatience, despair, selfishness and distrust ultimately leading towards being inhumane (hereby indicates severity of hatred towards self, society or system or members of society or all of these). In the cases whereby the economic and social problems exist, the mad-self starts with the fight for life but soon because of the fear of the unsatisfied needs for existence; it turns to be a fight of existence for the satisfaction of their unsatisfied basic needs.

\section{CRISIS AND HUMAN}

Human life is the combination of ups and downs, sorrow and happiness, gain and loss, and so on. Though it is a troubling couplet, it is essential, for without sorrow happiness cannot be felt and without darkness light cannot be experienced. Philosophically, human life is a journey to come out of this whimsical cycle of birth and death, young and old, sorrow and happiness, and gain and loss; the state of which is called Sthitpragya. This state can only be attained after prolonged intense spiritual practice. Spirituality doesn't mean practising religious activities blindly but it is all about having control on senses and ability to be ethical and just which is likely to be difficult for a person struggling to fulfil the needs. Every little gain makes him happy and loss turns him sad. Although even a little achievement is a joy for the family; an individual stepping out of the house (home refers to togetherness, love and oneness of family members, unfortunately today people have big houses but not home) is not sure to return safe and unhurt and to be precise anyone who leaves his house in the morning fails to come back with the same mood and mind set. Of course, it is not only the tiredness that impacts this mood and mind set. In fact, every step of the struggle is full of challenge and in extreme stages with danger to existence and life, it creates a crisis. These crises of human life attack the mind, health and psychology of person who turns the prisoner of his psychological conditions which need to check, if the psychological conditions of that individual could be changed or controlled? The response from the respondents although not being positive, hardly meant to be away from all worldly deeds rather it insisted to sway the unwanted worldly deeds. This further asks for the ways to help an individual come out of this trap and thus made it essential to understand the crisis which asked for the response in the form of Crisis Management (CM) for the Crisis Management Process (CMP). 


\section{RESEARCH QUESTIONS}

The wanted or unwanted, forced or willing choice as a response of the respondents to the conflicting forces emerged of the crisis is a step towards crisis management. Such a situation posits several questions as such - How do people respond to crisis? What is their mental status? How do people think in times of crisis? Do they respond to the crisis as a whole or compartmentalise it? As a part of crisis management, what are the series of steps people undergo while thinking to respond to the crisis? How do they feel at the end of crisis management? Such questions and thought process led to this study.

\section{OBJECTIVES OF THE STUDY}

The objective of the study included to study the process of crisis management which included to identify the essential characteristics that influence the process of crisis management; to develop the relationship between the characteristics that influence the process of crisis management and to develop a simple structure of the steps involved in the process of crisis management.

\section{HYPOTHESIS OF THE STUDY}

People undergoing a crisis face the barrier of helplessness but step ahead in several steps and stages to pacify their needs which serves as a basis to form the different steps of crisis management process.

\section{ASSUMPTION, PROPOSITION AND JUSTIFICATION THE STUDY}

It is a normal human and animal instinct that when they face the problem, they find their way. They either accept or reject the situation, struggle or surrender and thus either win or lose. The basic assumption for this study holds that people undergoing crisis face the barrier of helplessness but step ahead in several steps and stages to pacify their needs based on their insight, pre-experience, available resources, potential to minimise risk, and optimism. Although, they lack the formal knowledge of how to initiate preparation for a crisis threat but turn a part of the crisis to face it. This proposition also serves as justification of the research gap.

\section{METHODOLOGY OF THE STUDY}

The basic idea to direct the process for crisis management resulted the study in the form of a theoretical research. With the basis of articles focusing on crisis and crisis management, and their features in general, initially, the literature was discussed with experts and the respondents undergoing crisis.

The study was a mix of exploratory research, content analysis, analysis and synthesis, association analysis, thematic analysis and mind mapping. Whereas the exploratory research enabled to know the basics and whereabouts of the crisis management process; the content analysis, association analysis, thematic analysis, analysis and synthesis, and mind mapping served to prepare an appropriate basis to form the groups and thus the steps and stages for the crisis management process.

In order to obtain data, study was conducted on 220 people undergoing crisis. Interviews were conducted with the masons, factory workers, house keepers, maids and servants, 
salaried people and businessmen who responded as the respondents. Along with some basic demographic information, the questionnaire contained 20 questions as in appendix 1 . The research and results presented here were encouraged by the answers to the question: How did you prepare for the crisis? Respondents, being a part of crisis, answered as; trying to prevent crisis; preparing for household things; preparing with the requisites; collecting food and vegetables; minimizing the expenses; taking sufficient precaution; imposing suffice control; wait and watch; do nothing; care for the family needs; and others.

Content analysis and mind mapping was applied to portray the process of crisis management amongst the people. The analysis and synthesis were used to group the similar responses. Based on this analysis, several reasons were identified and based on synthesis several deductions were made for mind mapping which led to the visual representation of the stages in the process of crisis management. Association analysis was applied to connect and develop the relationship amongst the stages as well study the influence of the actions in each stage. Using a mind map and system analysis, a logical sequence of the characteristics and their relationships within the entire crisis management was established.

\section{IDENTIFYING AND DEVELOPING THE STRUCTURE OF CRISIS MANAGEMENT PROCESS}

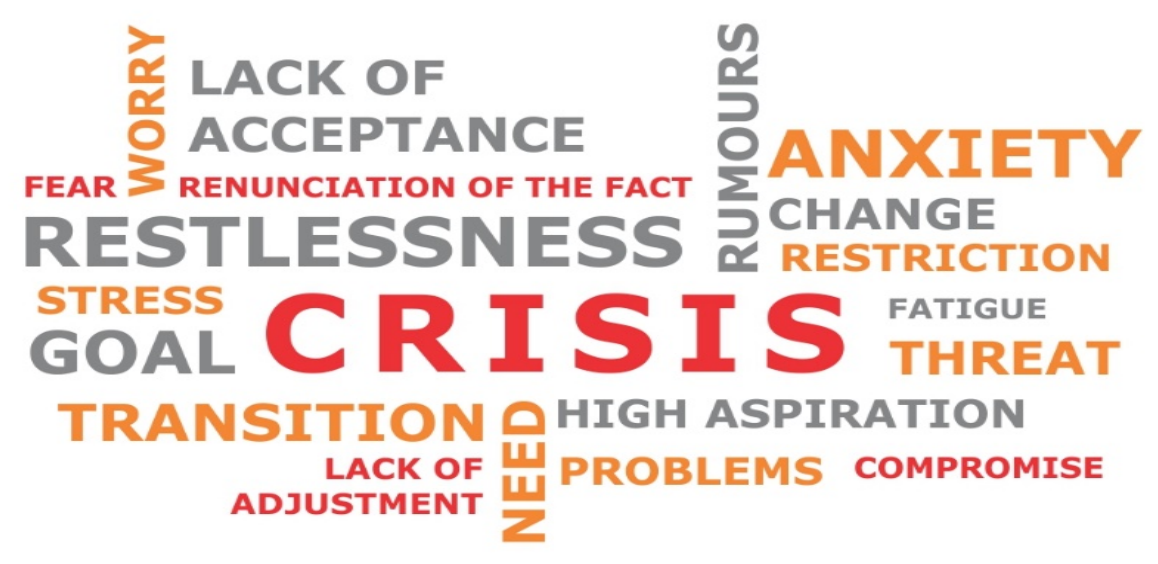

Figure 1 : Mind mapping of Reasons of Crisis Management

Initially a questionnaire was developed and a few people were interviewed. Probing questioning was applied to get the in-depth idea about how people feel about the crisis and how they react and respond to it. Based on this a mind map was applied to identify the basis, reason, determining factor, pacifying factor (possible choices) and its relationships which evolved a network (table 1). The figures evolved of the mind map are as in Figure 2, 3, 4. Table 2 presents the profile of 220 respondents and the frequency distribution of their response is as in figure 1. 
Table 1. Understanding the Process of Crisis Management

\begin{tabular}{|c|c|c|c|c|}
\hline $\begin{array}{l}\text { Sr. } \\
\text { No. }\end{array}$ & Basis & Reason & Determining Factor & Pacifying Factor \\
\hline 1 & $\begin{array}{l}\text { Threat of } \\
\text { existence/ } \\
\text { Meaning of one's } \\
\text { own stance }\end{array}$ & $\begin{array}{l}\text { Need, need satisfaction, SES, } \\
\text { aspirations, reason of living, outlook } \\
\text { towards life, goal }\end{array}$ & $\begin{array}{l}\text { Perception towards } \\
\text { life }\end{array}$ & $\begin{array}{l}\text { Empathetic } \\
\text { understanding }\end{array}$ \\
\hline 2 & $\begin{array}{l}\text { Transitional } \\
\text { Change in } \\
\text { environment }\end{array}$ & $\begin{array}{l}\text { Restrictions, threats of restrictions, fear } \\
\text { of situations, level of Fear of Situation, } \\
\text { fear of life and death, rumours, struggle } \\
\text { for existence, belongingness, peer } \\
\text { group influence, environment }\end{array}$ & Priorities of needs & $\begin{array}{l}\text { Ability to } \\
\text { overcome } \\
\text { shortcomings/ } \\
\text { shortfalls }\end{array}$ \\
\hline 3 & $\begin{array}{l}\text { Uncertainty of } \\
\text { External } \\
\text { Environment }\end{array}$ & $\begin{array}{l}\text { Sudden change in surrounding and } \\
\text { environment, self-restrictions, imposed } \\
\text { restrictions, foresightedness, } \\
\text { predictions, fear of forthcoming } \\
\text { situations, needs, SES, restriction of } \\
\text { needs, ability to cope up, self- } \\
\text { evaluation }\end{array}$ & $\begin{array}{l}\text { Efficiency to satisfy } \\
\text { the needs }\end{array}$ & $\begin{array}{l}\text { Level of } \\
\text { readiness }\end{array}$ \\
\hline 4 & Humility & $\begin{array}{l}\text { Positivity, belief in one's own ability, } \\
\text { confidence, anxious, apprehension, } \\
\text { ability, support }\end{array}$ & $\begin{array}{l}\text { Preparedness to } \\
\text { combat the situation }\end{array}$ & $\begin{array}{l}\text { Security/insecur } \\
\text { ity, idea and } \\
\text { threat of } \\
\text { existence }\end{array}$ \\
\hline 5 & Fear of Failure & $\begin{array}{l}\text { Acknowledging the reality, cooperative } \\
\text { and compliance, renunciating the fact, } \\
\text { Compromising, accepting the situation, } \\
\text { disturbed and misfit for society, } \\
\text { existence, survival and sustainability }\end{array}$ & Level of readiness & Restrictions \\
\hline 6 & $\begin{array}{l}\text { Trust in one's own } \\
\text { self or Trust in } \\
\text { God }\end{array}$ & $\begin{array}{l}\text { Appaling, atrocious, appealing, } \\
\text { attractiveness, Pleasure, Pain, } \\
\text { Confidence, Conceited }\end{array}$ & $\begin{array}{l}\text { Level of control on } \\
\text { consequences }\end{array}$ & $\begin{array}{l}\text { Assuring } \\
\text { safety/need }\end{array}$ \\
\hline 7 & Belief & $\begin{array}{l}\text { Tentative, thoughtfulness, bold, daring, } \\
\text { Morale }\end{array}$ & $\begin{array}{l}\text { Level of success on } \\
\text { predictions of } \\
\text { situations }\end{array}$ & $\begin{array}{l}\text { Idea of winning } \\
\text { over the } \\
\text { situation }\end{array}$ \\
\hline 8 & Self-Actualization & $\begin{array}{l}\text { Rationality, prudence, fulfilment, } \\
\text { common sense }\end{array}$ & $\begin{array}{l}\text { Level of } \\
\text { contentment }\end{array}$ & Purpose \\
\hline 9 & $\begin{array}{l}\text { Love/Respect for } \\
\text { all }\end{array}$ & $\begin{array}{l}\text { Adherence to belief, experience and } \\
\text { environmental factors, helplessness, } \\
\text { restlessness, livelihood, ethics, values, } \\
\text { morale }\end{array}$ & $\begin{array}{l}\text { Ability towards } \\
\text { sound judgement }\end{array}$ & Survival \\
\hline
\end{tabular}




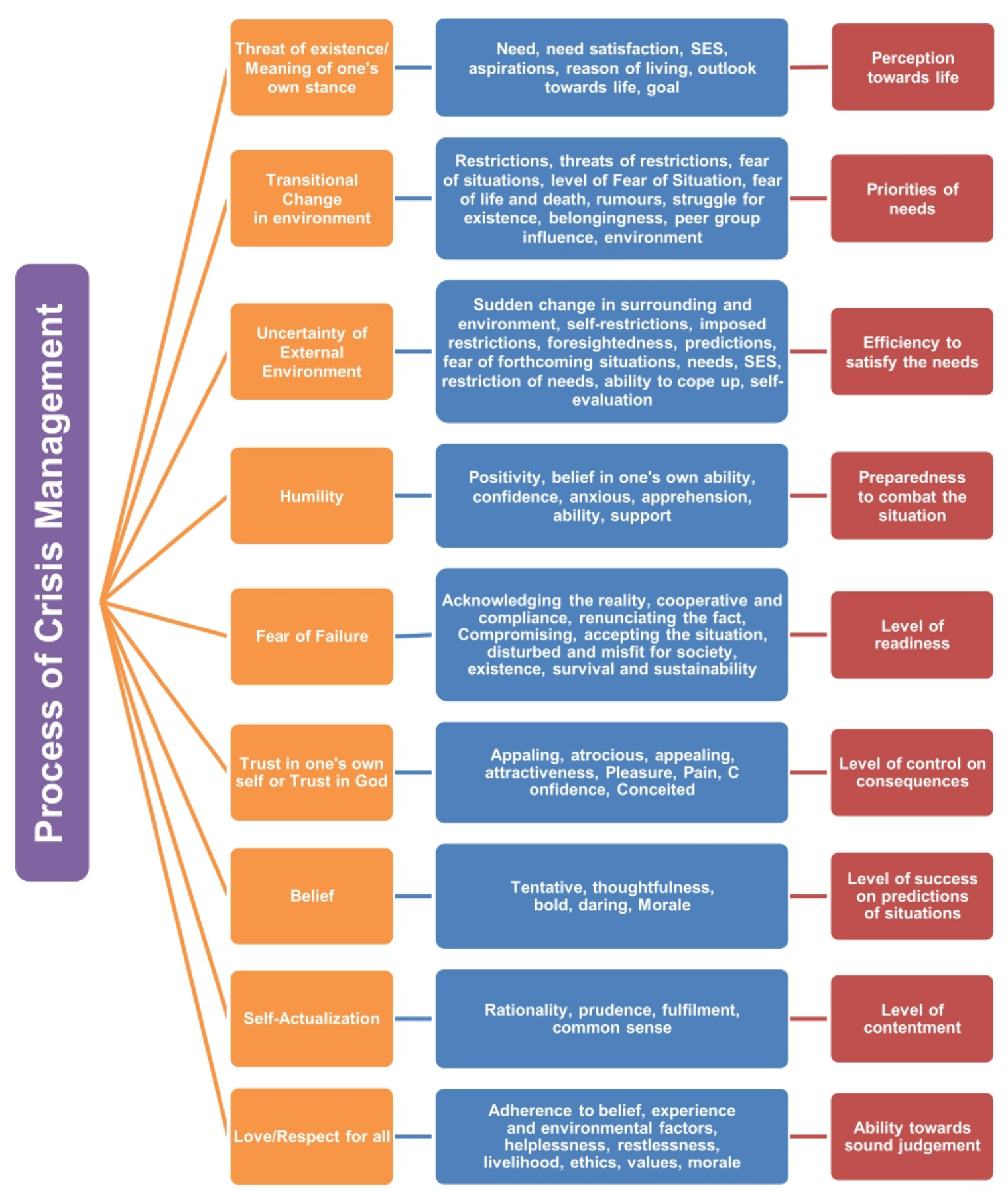

Figure 2 : Mind mapping of Process of Crisis Management 


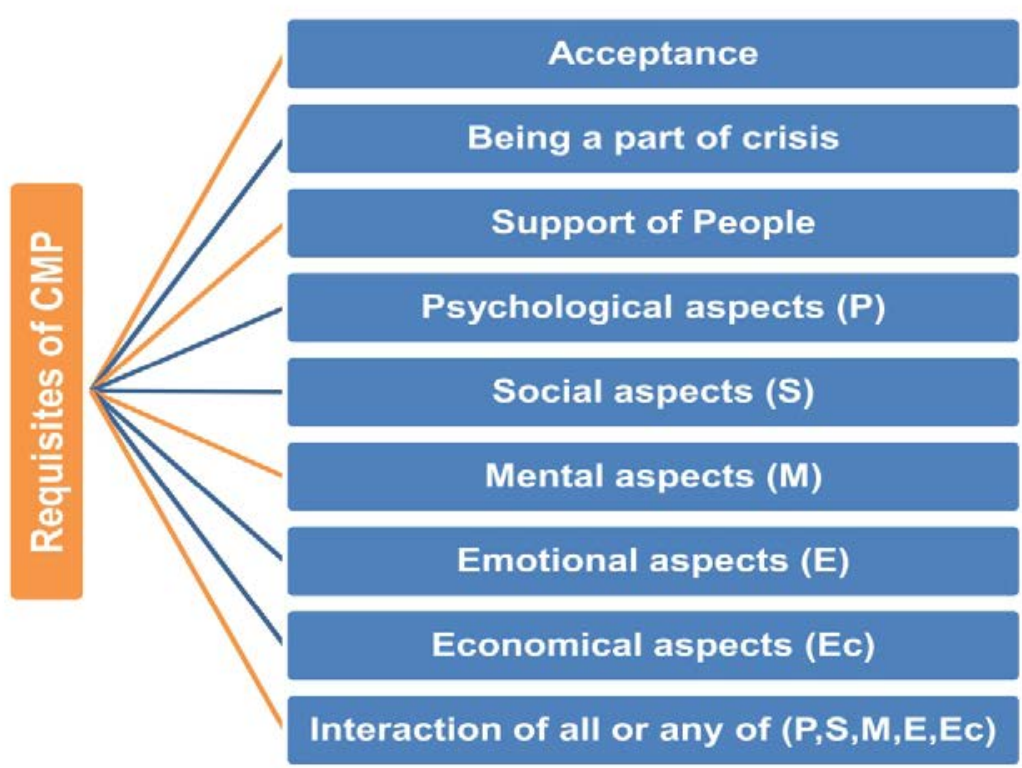

Figure 3 : Mind mapping of Requisites of CMP

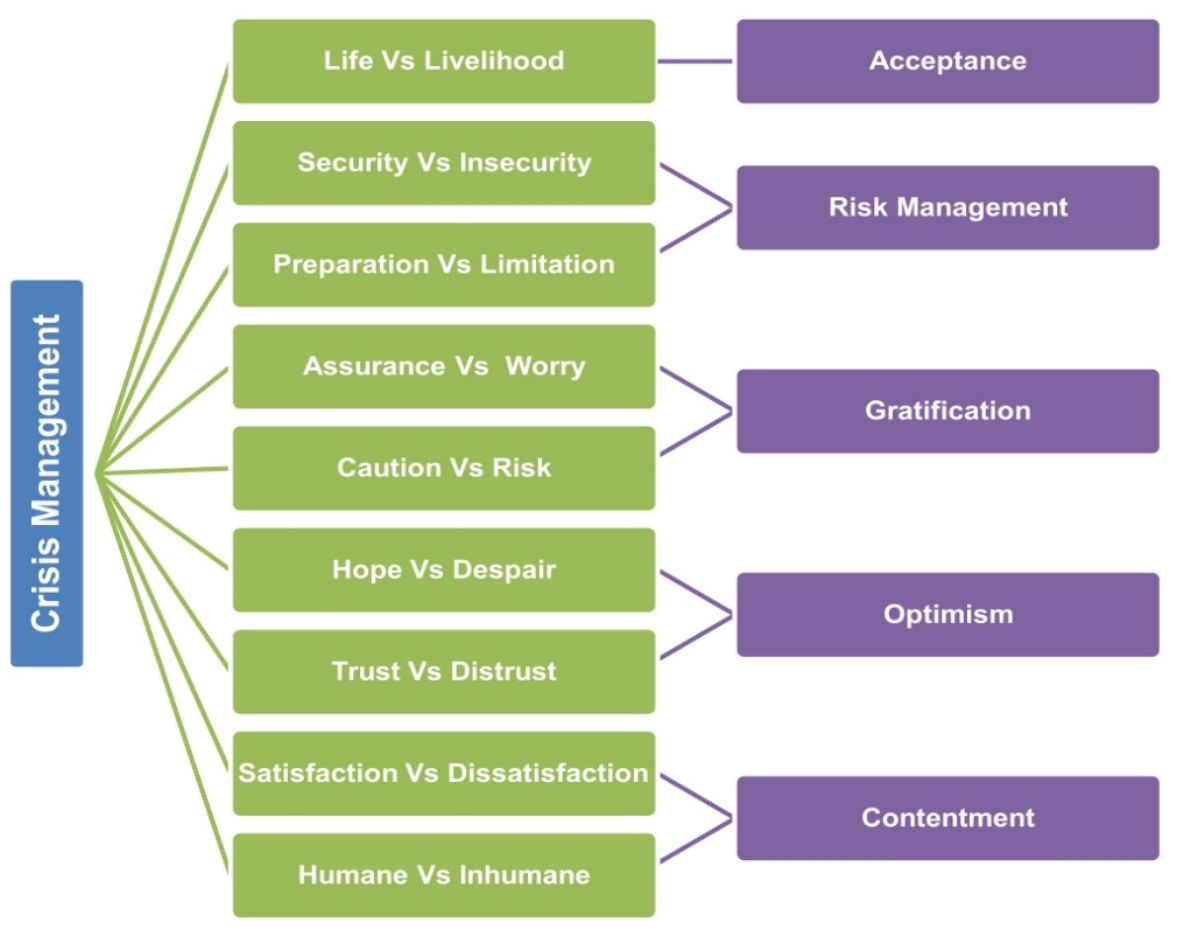

Figure 4 : Mind mapping of Crisis Management 


\section{REQUISITES/CONDITIONS OF CRISIS MANAGEMENT PROCESS}

Psychology, social, emotional and economic factors are the requisites for crisis management in the CMP. In-depth interviews indicated that the lack of psychology, social, emotional and economic factors impacted the life. The interrelation of these social factors, individuals thought and behaviour, emotions and economic factors influenced the human. The analysis of the responses showed the presence of characteristics which were grouped and presented in hierarchy of stages. Whereas on one side the hierarchy was listed with qualities leading towards humanity; on other side the hierarchy listed its contrast qualities more likely to lead towards being inhumane. It was observed that to prevent the crisis needs the support of the people in and around us, acceptance of the crisis, and the readiness to be a part of the crisis. If these requisites of crisis management for an individual are balanced and one has the capacity and ability to control it then one can identify, analyse, apply appropriate strategies, take appropriate decision and thus overcome the crisis. The strategies in crisis communication (crisis response strategy) take a special position (Noratikah, Aizza Maisha \& Mus Chairil, 2017).

\section{MIND MAPPING OF CRISIS MANAGEMENT PROCESS}

Further again, the mind map was applied which evolved the stages and substages of crisis management. The characteristics were identified and grouped based on their similarity which was used to develop their relationship and influences between them. Accordingly, a linear network structure with logical sequence of different stages having different levels (Figure 6) evolved as the hierarchical stages of CMP. The inclusion of characteristics in a stage represented the reasoning of that level. Based on the mind mapping of the grouped data of the respondents, the process of crisis management was broadly divided in five Stages of Crisis Management (SCM) with nine sub-stages in hierarchy. The five stages included 1) Acceptance; 2) Risk Management; 3) Gratification; 4) Optimism and 5) Contentment. Each stage had the hierarchy of sub-stages as in figure 7 with lowest level on top and highest at bottom.

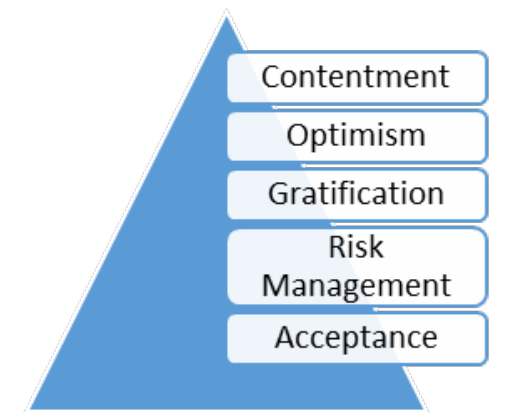

Figure 5. Pyramid Structure of Stages of Crisis Management Process

As shown in figure 5, the acceptance being the basic in hierarchy was placed at the bottom and the contentment being the highest in hierarchy was placed at the top in the pyramid structure which is similar to the Maslow's Need Hierarchy. Ofcourse, the level of readiness of an individual in each stage had the deep impact. The level of readiness of an individual in each stage determined their choice in the particular stage and influenced their level of entry 
in the next stage. The stages and sub-stages of the CMP are in hierarchy as in figure 8 with the lowest level on top and highest at bottom.

$\sum$ Acceptance $>$ Risk Management $>$ Gratification $>$ Optimism $>$ Contentment

Figure 6. Hierarchy in the Process of Crisis Management Process

Over all, after analysis, the characteristics with similar virtue, like reasons for cause and the like determining factors were grouped to form the stages. With each stage evolved the hierarchy of the sub-stages as conflicting forces as in figure 7. Figure 8 represents the comprehensive structure of the hierarchy of the CMP. When individuals reconcile with the sub-stages of a particular stage, they enter into other stage with its sub-stages with conflicting forces. Table 3 and table 4 presents the frequency of respondents for the substages and stages of CPM. From the table 4 it is vivid that in stage of crisis people accept it and choose life. In the next stage most of them find insecurity and thus the frequency on the other side seems to be rising in this stage but as they initiate for preparation to overcome their limitation, this frequency decreases gradually in other stages and leads toward humane in the stage of contentment.

\begin{tabular}{ll}
\hline \begin{tabular}{l} 
Sub-stages of $\begin{array}{l}\text { Crisis } \\
\text { Management }\end{array}$ \\
\cline { 2 - 2 }
\end{tabular} & Life Vs Livelihood \\
\cline { 2 - 2 } & Pecurity Vs Insecurity \\
\cline { 2 - 2 } & Pssurance Vs Worry \\
\cline { 2 - 2 } & Caution Vs Risk \\
\cline { 2 - 2 } & Hope Vs Despair \\
\hline & Trust Vs Distrust \\
\hline & Satisfaction Vs Dissatisfaction \\
\hline
\end{tabular}

Figure 7. Hierarchical Sub-stages of Crisis Management Process

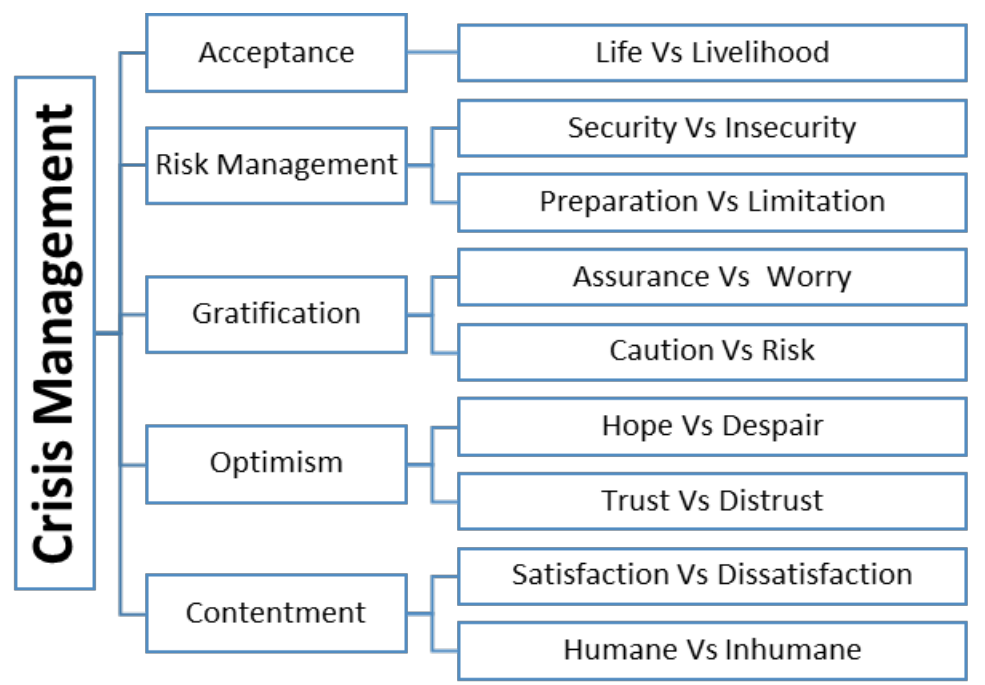

Figure 8. Hierarchy of Stages and Sub-stages of Crisis Management Process 
Table 3. Frequency of responses of respondents for sub-stages of CPM

\begin{tabular}{|c|l|c|c|}
\hline Sr. No. & $\begin{array}{c}\text { Sub-stages of Crisis in the form } \\
\text { of Conflicting Forces }\end{array}$ & $\begin{array}{c}\text { Frequency of responses } \\
\text { for first choice }\end{array}$ & $\begin{array}{c}\text { Frequency of responses for } \\
\text { Second choice }\end{array}$ \\
\hline $\mathbf{1}$ & Life Vs. Livelihood & 208 & 12 \\
\hline $\mathbf{2}$ & Security Vs. Insecurity & 32 & 188 \\
\hline $\mathbf{3}$ & Preparation Vs. Limitations & 102 & 118 \\
\hline $\mathbf{4}$ & Assurance Vs. Worry & 123 & 97 \\
\hline $\mathbf{5}$ & Caution Vs. Risk & 151 & 69 \\
\hline $\mathbf{6}$ & Hope Vs. Despair & 144 & 76 \\
\hline $\mathbf{7}$ & Trust Vs. Distrust & 146 & 74 \\
\hline $\mathbf{8}$ & Satisfaction Vs. Dissatisfaction & 148 & 72 \\
\hline $\mathbf{9}$ & Humane Vs. Inhumane & 152 & 68 \\
\hline
\end{tabular}

Table 4. Frequency of responses of respondents for stages of CPM

\begin{tabular}{|c|l|c|c|}
\hline $\begin{array}{c}\text { Sr. } \\
\text { No. }\end{array}$ & Stages of Crisis & Frequency of responses in Each Stage & Frequency of responses in Each Stage \\
\hline $\mathbf{1}$ & Acceptance & 208 & 12 \\
\hline $\mathbf{2}$ & Risk Management & 67 & 153 \\
\hline $\mathbf{3}$ & Gratitude & 137 & 83 \\
\hline $\mathbf{4}$ & Optimism & 145 & 75 \\
\hline $\mathbf{5}$ & Contentment & 150 & 70 \\
\hline
\end{tabular}

\section{UNDERSTANDING THE STAGES AND SUB-STAGES OF CRISIS MANAGEMENT}

\subsection{Acceptance}

There are different beliefs about the origin and existence of human life. Whatever be the response, the fact about the origin and existence remains undeterred and from the day of life getting into the body, the struggle for survival begins with struggle to fulfil the physical, physiological, psychological, social needs etc. But human is not always lucky enough to get that what he wants. Whether willingly or unwillingly, human and animals accept all that is bestowed by nature, God or almighty. With respect to human, all the situations in life are not so good to be welcomed and accepted whole heartedly but they do accept it. Life with misery, sufferings, pain, accidents, poor health, being specially gifted etc. and even death are such events which no one likes and thus individuals show their rejection, anger, worry etc. but finally whether willingly or unwillingly they do accept it. The situations whereby individuals face the unwanted and disliking situation and are forced to accept it whether willingly or unwillingly refers to Acceptance. There starts the CMP. Based on the readiness to face the situation depend the level of acceptance. With the unwanted happenings risking the life, the individuals represent their denial, anger, anxiety, stress, frustration, wander for options, get depressed but ultimately with nothing for the option, they accept it and initiate with CMP. Here, they enter into the first stage of CMP viz. acceptance. This stage allows the individual to enter the first sub-stage of CMP viz. life Vs livelihood the level of likeliness for which determines their level of entry in next stage.

\section{i.Life Vs Livelihood}

In any case of problem with fear of losing the life or the loss equivalent to the loss of life, the individual comes across this crisis. With several reasons for this sub-stage as in table 2 
people start pondering this sub-stage as a threat to life/existence and livelihood. Based on their understanding people determine their choice and make a selection. With this choice the individual enters into another sub-stage of $\mathrm{CM}$ security Vs insecurity. With any huge change, individuals enter the first stage of the crisis and ponder if they should think of rejoicing life or strive for existence. During this pandemic, more than the virus, the sudden exaggeration of the pandemic and the imposed sudden decisions created the terror in human mind which forced each one whether economically stable or unstable to pass through this sub-stage.

Table 2. Respondents Profile

\begin{tabular}{|c|c|c|c|c|c|c|}
\hline Features & Masons & $\begin{array}{c}\text { Factory } \\
\text { Workers }\end{array}$ & $\begin{array}{c}\text { House } \\
\text { Keepers }\end{array}$ & $\begin{array}{c}\text { Maids and } \\
\text { servants }\end{array}$ & $\begin{array}{c}\text { Employees } \\
\text { in Job }\end{array}$ & Businessman \\
\hline $\begin{array}{c}\text { No. of } \\
\text { respondents }\end{array}$ & 35 & 32 & 25 & 50 & 38 & 40 \\
\hline $\begin{array}{c}\text { No. of Family } \\
\text { members }\end{array}$ & $4-7$ & $4-7$ & $4-6$ & $4-6$ & $2-4$ & $3-4$ \\
\hline Annual Income & $\begin{array}{c}\text { Less than } \\
\text { 1 lakh }\end{array}$ & $\begin{array}{c}\text { Less than 1 } \\
\text { lakh }\end{array}$ & $\begin{array}{c}\text { Less than 1 } \\
\text { lakh }\end{array}$ & $\begin{array}{c}\text { Less than 1 } \\
\text { lakh }\end{array}$ & $5-10$ lakh & $\begin{array}{c}10 \text { lakh and } \\
\text { more }\end{array}$ \\
\hline
\end{tabular}

E.g. Everyone with love for life was shocked and shattered with the sudden imposed controls. Most of them were angry, had anxiety and were depressed but with no solution accepted the situation and responded to the stimuli. It was here, everyone, with the fear of the danger on their existence in this pandemic chose for life and abhorred livelihood but the situation was not alike throughout and many people who desired the choice of life were forced for livelihood to ascertain their existence through their economic stability. These were the one who risked their life. Some worked from home and some took risk on their own to satisfy their basic needs. For individuals who could do nothing, each one stayed where they were because they were unknown of what is going to happen next and for how long such situation was to continue. Most of the ignorant and innocent mind and heart thought of only that what was said and accepting the situation with positive contemplation towards the system, they opted to choose life which forced them to enter the next stage and thus prepare themselves for the response to its sub-stages in the form of conflicting forces.

\subsection{Risk Management}

When a child grows, he develops the likes and dislikes, love and anger, rejection and acceptance etc. which in most cases turns to be the cause of pain, unhappiness and sorrow; the excess of which provokes the individuals with the feeling of their life at risk and this causes crisis in life which demands adjustment. The adjustment itself means tug of war. Tug of war is a crisis which asks for critical adjustment with the environment. Merely with acceptance of the situation, the war is not won. In fact, it has just initiated and demands the move towards next step. Having accepted the unwanted situation and clearing the first stage of the crisis; the individuals are forced only to ensure their safety and security which enforces risk assessment, minimizing the risk, conducting their SWOT analysis and thus the individuals enter the stage of risk management. In any crisis, Risk Management refers to the process of minimising the assessed dangers, limitations and constraints which may prove to be a hurdle in the coming days if not resolved now. Based on the level of overcoming the constraints or limitations depend the level of risk management. This stage includes two sub- 
stages in hierarchy viz. security Vs insecurity and preparation Vs limitation which determines their level of readiness in that particular stage.

\section{ii. Security Vs Insecurity}

With the basis of transitional change in their environment, individuals enter this stage and start pondering about their security vis-à-vis insecurity. With several reasons for this substage as in table 2 the individuals determine their choice based on their ability to overcome shortfalls. Pacifying themselves they enter the next sub-stage viz. Preparation Vs limitation of this stage.

E.g. With the idea of loss of job or failure in life, the individuals start evaluating oneself for security and insecurity. With the message of imposed lock down, each one entered this stage and started evaluating about their security. Those economically sound and stable even thought for their luxury whereas others started evaluating their security with respect to the satisfying of their needs. Whether businessman, management, employee or worker; each of them entered this stage to assess their security vis-a-vis insecurity. This was the situation, when even those who were on pay roll felt unsecured. Having evaluated their level of security, the individuals enter the third sub-stage of the $\mathrm{CM}$.

\section{iii. Preparation Vs Limitations}

Having reconciled with the second sub-stage, based on the uncertainty of external environment individuals enter this stage whereby they assess and evaluate their shortfalls and plans to remain devoid of the shortfalls. With several reasons for this sub-stage as in table 2 the individuals determine their choice based on their level of readiness to cope up with this sub-stage. Hereby, the individuals evaluate themselves with their preparation and limitation.

E.g. With the sudden lockdown and closure of all shops, with respect to the materialistic objects and things, the people having evaluated their security rushed to the shops to buy all that they could. Those who were economically sound flooded their house with the requirements whereas others tried to get whatever they can buy within their limits. Those with good network and resources prepared themselves well whereas others kept on striving to prepare them for this war. The economic stability of the individual, their network and resources played an important role which decided the level of that stage. With this preparation, each one enters the other stage of CMP viz. gratification and prepared themselves to respond to its sub-stage.

\subsection{Gratification}

Gratification here means pleasing or displeasing oneself by satisfying their needs in the form of materialistic object or things with high temporal value. Based on the level of pleasing and displeasing oneself with the choices of the stage depends the level of gratification. The psychological state of the individuals was shattered drastically of course, due to COVID 19 but more because of its weird and wild exaggeration that imprisoned the people on the TV set. The sudden presentation of the numbers of cases across the world created a panic but having prepared themselves, the individuals entered the stage of gratification. With the entry in this stage, the individuals came across two sub-stages viz. assurance Vs worry and caution 
Vs risk which determines their level of readiness in this stage and hence their level of entry in the other stage.

\section{iv. Assurance Vs Worry}

The level of preparation is the basis for the entry in this stage. With several reasons for this sub-stage as in table 2 the idea of level of threat of sustenance which is based on the level of preparation in the last sub- stage determined the individual's choice in this sub-stage.

Based on the choice in the third stage the individual enters the fourth stage whereby they assess themselves with their preparation and either gets assured or start worrying. Those who were successful with preparation remained assured but those daily wage workers and others who had limitations had nothing less than to worry. Noteworthy that the fear of being infected, not being open and free to move and meet people, no regular source of income due to lock down impacted the mental health. A person in UP killed himself for not being able to take care of his family due to lock down (as mentioned in his death note). This incident is sufficient to understand the gravity of psychological state of people which indicates that the earlier steps were not only related to materialistic requirements but extended to every aspect of life. This sub-stage thus led the individuals to the next sub-stage of this stage.

\section{v. Caution Vs Risk}

The level of humility forms the basis of this stage. With several reasons for this sub-stage as in table 2 the level of restrictions determines the individual's choice in this stage. Now, the individuals, if they are assured, they tend to bear patience and thus behave cautiously by being awful to law and governance whereas those who are not assured, they keep striving for need gratification and thus are prone to take risk along with being unawful to law and governance. Those prepared with their needs have patience that enables them to control themselves and thus tend to believe in caution whereas others take risk. In any case of crisis those people who satisfy their needs have patience and looks upon the situation with caution whereas those who are unable to gratify their needs they take risk.

E.g. In this pandemic, the labour class who were left with only to worry because of their insecurity and limitations believed in the words of government and took caution but with their situation getting worse soon they felt that the government failed to gratify their needs and then they took risk. The vague and panicked decisions of the authorities proved to be fatal destroying all the norms including social distancing. Depending upon the level of readiness of the individual to fight the war in this sub-stage was determined their choice which forced them to enter the next stage viz. Optimism and its sub-stage.

\subsection{Optimism}

Things being tough during pandemic presented different facets of human which represented the different level of human values. In any tough time, it's only the society that cares for the society and accordingly people came out generously helping the needy, atleast with food; although they knew that they were also in the similar conditions. This represented the hopeful attitude of the society and their trust. Simultaneously, it worked more for those who seeked the help and added to their Optimism. Optimism is the result of the belief either in self, unknown entity or the governance which results of the level of fulfilment of the hopes and the level of trust that arose out of hopes. Based on the level of fulfilment of hopes 
depends the level of trust and so depends the level of Optimism. Optimism leads towards faith which leads towards contentment. Faith is matter of an individual's life, his belief system and way of living. Noteworthy here that apart of the other donations, people were very optimist to donate to the care funds at both central and state level. It is thus rightly believed that only the society helps the society and its individuals. Media also played an important role here. A few media became sensitive and showed their love, concern and respect for all suffering people and their family. It was the Optimism whether in nature, unknown entity or self which prompted the people to be generous and thus no one asked anybody's religion, caste or any other information. They just helped. Depending upon the degree of their readiness to fight the war against betrayal of Optimism, the individuals enter this stage with readiness to respond to the two sub-stages of conflicting forces viz. hope Vs despair and trust Vs distrust.

\section{vi. Hope Vs Despair}

The suffering that people had undergone determines the individual's choice in this stage. With several reasons for this sub-stage as in table 2 the level of readiness in the earlier stage determines the individual's choice in this stage. Hereby, the individuals have a choice of hope or despair. Those fulfilling their need with caution and having the power of money and resources remain updated and tend to have hope whereas others taking risk and failing to gratify their needs undergo despair.

E.g. Many people who couldn't gratify their needs lost patience and took risk of moving to their safe surrounding even in this unsafe environment. Although in despair, it was the hope and positive attitude towards life, survival or existence that boosted many people to move towards their native. The failure of the promises by the government, the long waiting, poor economic conditions, failure to get work and salary that led these people nearly to starve and turned them to take this hopeful decision of high risk even in the state of despair. Again, the level of readiness in this stage determines their level of entry in next sub-stage.

\section{vii. Trust Vs Distrust}

The happenings in the earlier stage, the basis of belief etc. determines the individual's choice in this stage. With several reasons for this sub-stage as in table 2 the level of success in earlier stage determines the individual's choice in this stage. Hereby, the individual has a choice of trust or distrust. Those who are hopeful and get success in their hopes gain trust and others who end with despair develop distrust.

E.g. The labourers who waited a long time with despair developed distrust towards the governance and the society. The pathetic conditions they suffered developed distrust towards the system and the government. Not getting salaries, unable to pacify the basic needs, hopelessness led them in despair and strong distrust. People away from their families, accidents during the pandemic, inhuman attitude of the government, vague decisions affirmed the distrust and it was pity, most of the people were in despair. Again, the level of readiness in this stage determined their level of entry in other stage viz. contentment and its sub-stages viz. satisfaction Vs dissatisfaction, humane Vs inhumane. 


\subsection{Contentment}

This last stage of CMP ends with contentment. Contentment hereby means the inner feeling of joy that thrills the individual's body, mind and soul with the idea of having his highest achievement. Based on the level of satisfaction depends the level of being humane and so is the level of contentment. Contentment deals with satisfaction and thus humanity. The contentment adds to the tendency of being humane and discontentment leads to being inhumane. If you get that what you want, you are satisfied. This satisfaction adds to joy and thus adds to the individual to be more humane. Simultaneously if you are dissatisfied, you are more prone to turn inhumane by being cruel, harsh etc. Whether economically stable or unstable, each individual started with life. Each one travelled through all the five stages and its sub-stages. But a huge part of the society was forced to take risk which ended up with distrust. Luckily because of their low and poor morale, their being inhumane didn't affect the society rather they were again the members of the first stage to start their journey a fresh. This stage of contentment leads the individuals towards the two sub-stages viz. satisfaction Vs dissatisfaction and humane Vs inhumane.

\section{viii. Satisfaction Vs Dissatisfaction}

With several reasons for this sub-stage as in table 2 the level of limiting the needs towards the idea / object determines the individual's choice in this stage. The purpose determines the individual's choice in this stage. Hereby, those who have the opportunity to choose assurance, caution and hope of the conflicting forces of the sub-stages add to their trust and thus to their satisfaction whereas others whose destiny force them to opt for risk and despair end up with distrust and thus dissatisfaction.

E.g. The migrant labourers who were forced to take the risk underwent huge sufferings which included day and night walking, remaining without food and water, inappropriate health and hygiene conditions, sleepless nights, stress, pain, loss of family members in this journey etc. remained dissatisfied. Although the last minutes train run by the government was a matter to add to their satisfaction but unfortunately the huge charges, inappropriate arrangement, lack of planning added to the risk to each sufferer creating a chaos and dissatisfaction to them. Similarly, the crazy guidelines for the employees, insisting the employees to start their work from the work place without providing any facilities, salary cut etc. led to the strong dissatisfaction among the people which added to the existing differences of employees/workers and management. This led them to enter to the next and last stage of CMP

\section{ix. Humane Vs Inhumane}

With several reasons for this sub-stage as in table 2 the love and respect for all determines the individual's choice in this stage. The survival determines the individual's choice in this stage. In any case, people start with the idea of security with positivity towards life but only a few reaches towards end. With economic support and ability to survive, those people with the choice of life, ended up with life but of these people only those with generosity ended up with being humane. Most of the rich ended up being with inhumane.

E.g. Most of the people who started for life because of lack of economic support ended up with helplessness and some of them even lost life. At this time there were only a few who 
behaved normally and ended up being humane. It was unfortunate that the crisis started with selection of life but many had to think for livelihood and most lost their lives.

The willing or unwilling choice of the respondents to the conflicting forces emerged of the crisis was a step towards crisis management process. From the data analysis it was clear that the hypothesis that people undergoing a crisis face the barrier of helplessness but step ahead in several steps and stages to pacify their needs which serves as a basis to form the different steps of crisis management process is not rejected. Thus, it could be said that the people undergoing a crisis face the barrier of helplessness but step ahead in several steps and stages to pacify their needs which serves as a basis to form the different steps of crisis management process. A linear network structure with logical sequence of different stages having different levels evolved as the hierarchical stages of CMP. Accordingly, the process of crisis management was divided in five SCM with nine sub-stages in hierarchy. The five stages included acceptance; risk management; gratification; optimism and contentment. With each stage evolved the hierarchy of the sub-stages as conflicting forces. Only when individuals reconcile with the sub-stages of a particular stage, they enter into other stage and sub-stages with conflicting forces. It is vivid that during any initial stage of crisis whether willingly or unwillingly, people accept it and choose life. In the next stage, with insecurity they initiate for preparation to overcome their limitation, sooner or later which leads toward humane in the stage of contentment.

\section{CONCLUSION}

The objective of this study was to direct the process for crisis management. The results are based on theoretical research. With the basis of several articles focusing on crises and crisis management, and their features in general, the literature was discussed with experts and the respondents undergoing crisis which formed the basis for the creation of the crisis management process. In order to obtain data, interviews were conducted with masons, factory workers, house keepers, maids and servants, salaried people and businessmen. Exploratory research, content analysis, thematic analysis, analysis and synthesis, mind mapping and association analysis were applied to understand the process of crisis management. Using a mind map and content analysis, a logical sequence of the elements and their relationships within the entire crisis management process was established which offered five stages and nine sub stages of crisis management. Although care has been taken to establish these stages and sub-stages but it needs to verify and ascertain these stages in alike situations which necessitates further researches.

\section{REFERENCES}

Civelek, M. E., Csemberci, M., \& Eralp, N. E. (2016). The role of social media in crisis communication and crisis management. International Journal of Research in Business and Social Science (2147-4478), 5(3), 111-120. doi:10.20525/ijrbs.v5i3.279

Coombs, T., \& Hollady, S. J. (2012). The handbook of crisis communication. New York: Wiley.

Coombs, W. (2007). Ongoing crisis communication: Planning, managing and responding (2nd ed.). Thousand Oaks: Sage. 
Hart, P., Heyse, L., \& Boin, A. (2001). New trends in crisis management practice and crisis management research: Setting the Agenda. Journal of Contingencies and Crisis Management, 9(4), 181-199. doi:10.1111/1468-5973.00168

Litovchenko, Y. (2012). The choice and justification the strategy of enterprise crisis management. B`ıznes Inform, 12, 308-312.

Marie Mikušová \& Petra Horváthová (2019) Prepared for a crisis? Basic elements of crisis management in an organisation, Economic Research-Ekonomska Istraživanja, 32:1, 1844-1868, DOI: 10.1080/1331677X.2019.1640625

Maslow, A. H. (1954). Motivation and personality. New York: Harper and Row.

Maslow, A. H. (1962). Toward a psychology of being. Princeton: D. Van Nostrand Company.

Maslow, A. H. (1970a). Motivation and personality. New York: Harper \& Row.

Maslow, A. H. (1970b). Religions, values, and peak experiences. New York: Penguin. (Original work published 1966)

Maslow, A. H. (1987). Motivation and personality (3rd ed.). Delhi, India: Pearson Education.

Mir, U. R., Hassan, S. S., Ali, A., \& Kosar, R. (2016). New knowledge creation and crisis management team's performance. Science International, 28(3), 2831-2836.

Mitroff, I. I. (2003). Crisis leadership: Planning for the unthinkable. Hoboken, USA: Wiley.

Mitroff, I., Pauchant, T., Finney, M., \& Pearson, C. (1989). Do (some) organizations cause their own crises? The cultural profiles of crisis-prone vs. crisis-prepared organizations. Organization and Environment, 3(4), 269-283. doi:10.1177/108602668900300401

Noratikah, M. A., Aizza Maisha, D. A. A., \& Mus Chairil, S. (2017). Crisis response strategy and crisis types suitability: A preliminary study on MH370. Paper presented at the International conference on communication and media: An international communication association regional conference (i-COME'16), Kuala Lumpur, Malaysia, 33. doi:10.1051/ shsconf/20173300037

Pearson, C. M., \& Clair, J. A. (1998). Reframing crisis management. Academy of Management Review, 23(1), 59-78.

T`anase, D. I. (2012). Procedural and systematic crisis approach and crisis management. Theoretical and Applied Economics, 5(569), 177-184. 


\title{
APPENDIX: Crisis Management Questionnaire
}

\author{
Name \\ Work \\ Mason/Factory worker/House keeper/Maid or Servant/Employee with a \\ No. of Family \\ Members \\ $2 / 3 / 4 / 5 / 6 / 7$ \\ Type of \\ Remuneration Daily/Monthly/Project based \\ Annual \\ Income \\ Less than 1 lakh/1-5 lakh/5-10 lakh/more than 10 lakh \\ Sr. No. \\ Questions \\ $2 \quad$ How did often did you come across such a situation? \\ $3 \quad$ Will you term it as normal or consider it as crisis? \\ $4 \quad$ How did you prepare for the crisis? \\ 5 What was the first thought that came to your mind with the idea of lock down? \\ $6 \quad$ How did you react to the idea of complete lock down? \\ $7 \quad$ Did you get enough time to prepare with the situation? \\ $8 \quad$ What was the first thing you did after hearing about lock down? \\ $9 \quad$ List the things which you decided to collect with the lock down? \\ $10 \quad$ With these forced restrictions - what did you select - life or livelihood? \\ 11 How did you strive to protect/secure yourself with the crisis? \\ 12 What did you do to prepare yourself with the situation? \\ 13 Were you assured with your preparation? \\ $14 \quad$ Did you take any risk to fulfil your needs? \\ $15 \quad$ Were you able to get all that you desired? \\ 16 How did you feel with the lack of fulfilment of your desires? \\ $17 \quad$ What did you do then? \\ 18 How optimistic you are about your well-being in this situation? \\ 19 Are you satisfied with all the happenings with you? \\ $20 \quad$ How do you feel now with the happenings till now?
}




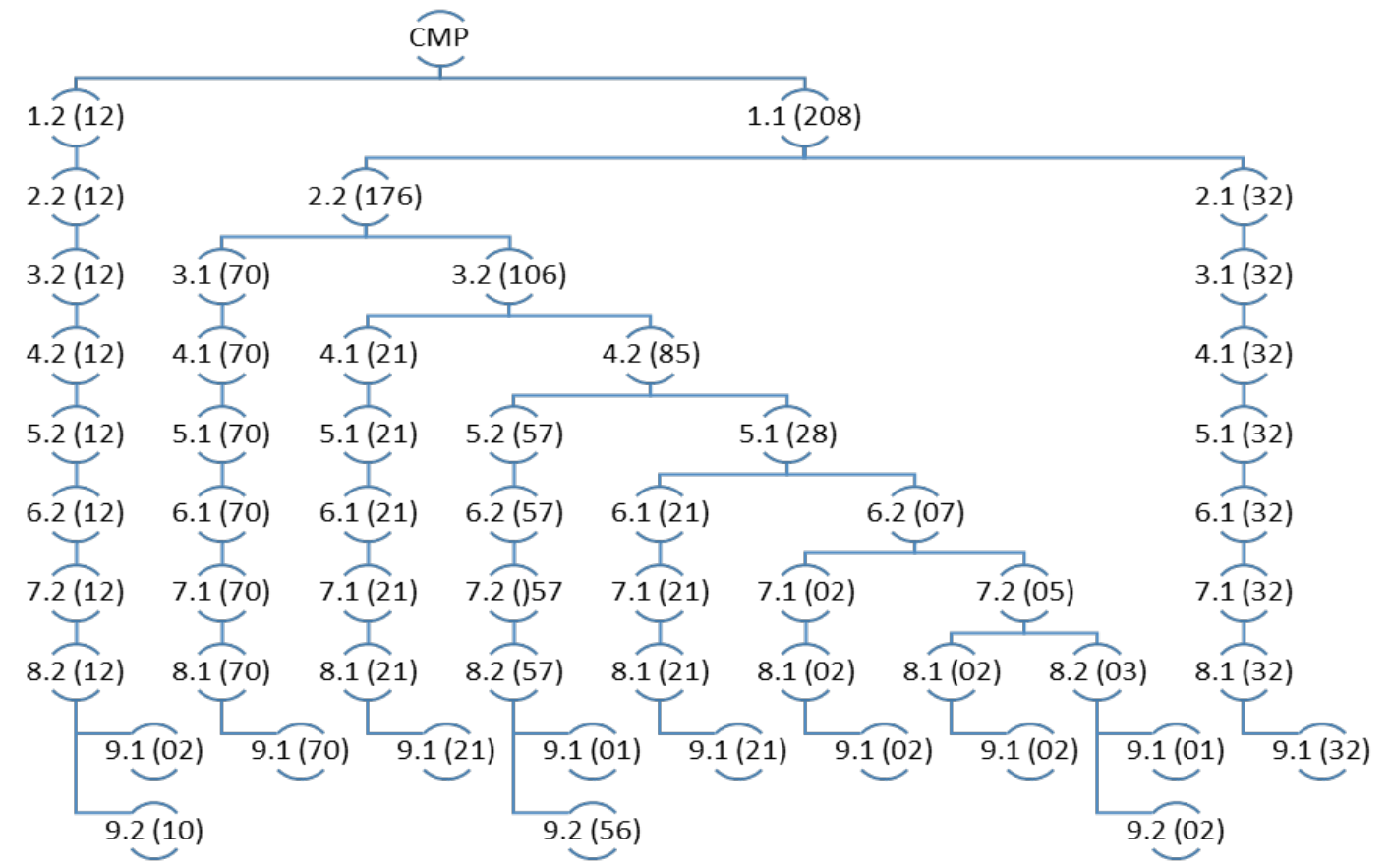

Figure 9. Networking of Sub-stages of CMP 